\begin{tabular}{|c|c|c|}
\hline & International Journal of Current Research in \\
Biosciences and Plant Biology & Volume $5 \bullet$ Number 3 (March-2018) • ISSN: 2349-8080 (Online) \\
\hline EXCELLENT \\
PUBLISHERS
\end{tabular}

\title{
Preliminary Biochemical Analysis of the Ethanolic Leaf Extract of Holoptelea integrifolia Planch. (Family-Ulmaceae)
}

\author{
B. Nithya and M. Arul Sheeba Rani* \\ Department of Botany, Nirmala Collage for Women, Coimbatore- 641 018, Tamil Nadu, India
}

${ }^{*}$ Corresponding author.

\begin{tabular}{|c|c|}
\hline Article Info & ABSTRACT \\
\hline $\begin{array}{l}\text { Date of Acceptance: } \\
23 \text { February } 2018\end{array}$ & \multirow{4}{*}{$\begin{array}{l}\text { Medicinal plants have assumed greater importance in the recent days, due to the } \\
\text { tremendous potential they offer in formulating new drugs which afflict humankind } \\
\text { against many diseases. There is now a growing focus on the importance of medicinal } \\
\text { plants and the traditional health system is solving the healthcare problems of the } \\
\text { world. Most developing countries have viewed traditional medical practice as an } \\
\text { integral part of their culture. Medicinal plants have curative properties due to the } \\
\text { presence of various complex chemical substances of different composition, which are } \\
\text { found as secondary metabolites in one or more parts of the plants. Hence, the present } \\
\text { study was undertaken to find out the biochemical analysis of an important medicinal } \\
\text { tree Holoptelea integrifolia was selected from the Nirmala College campus. The young } \\
\text { and the matured leaves were powdered and extracted with the ethanolic solvent. The } \\
\text { extracts were subjected to biochemical analysis using standard methods. }\end{array}$} \\
\hline $\begin{array}{l}\text { Date of Publication: } \\
06 \text { March } 2018\end{array}$ & \\
\hline Keywords & \\
\hline $\begin{array}{l}\text { Biochemical analysis } \\
\text { Ethanol leaf extract } \\
\text { Holoptelea integrifolia } \\
\text { Medicinal plants } \\
\text { Phytochemicals }\end{array}$ & \\
\hline
\end{tabular}

\section{Introduction}

Medicinal plants are a source of great economic value in the Indian subcontinent. Nature has bestowed on us a very rich botanical wealth and a large number of diverse types of plant grow in different parts of the country. Phytochemicals (from the Greek word 'phyto', meaning 'plant') are biologically active, naturally occurring chemical compounds found in plants, which provide health benefits for humans further than those attributed to macronutrients and micronutrients (Hasler et al., 1999). They protect plant from disease and damage and contribute to the plants colour, aroma and flavour. In general, the plant chemicals that protect plant cells from environmental hazards such as pollution, stress, drought, UV exposure and pathogenic attack are called as phytochemicals (Gibson et al., 1998). Recently, it is clearly known that they have roles in the protection of human health, when their dietary intake is significant. More than 4000 phytochemicals have been cataloged and are classified by protective function; physical characteristics and chemical characteristics. Biochemical's are essential nutrients and are required by the human body for sustaining life. Carbohydrates and proteins are macronutrients. 


\section{Materials and methods}

\section{Study area (Fig. 1)}

Tamil Nadu is one of the 28 states in India. Its capital is Chennai (Formerly known as Madras) the largest city. Tamil Nadu lies in the southern most part of the Indian peninsula and is bordered by the union territory of Puducherry and the states of Kerala, Karnataka and Andhra Pradesh. Coimbatore is the city in Tamil Nadu, South India. It is the capital city of Kongunadu region and is often been referred to as the Manchester of South India. The Nirmala College is situated in the district of Coimbatore, which has a pleasant climate due to the presence of forests to the north and the cool winds blowing through the Palghat gap in the Western Ghats. The College campus is pollution free and eco-friendly. It is filled with more number of medicinal trees and has a rich Botanical Garden.

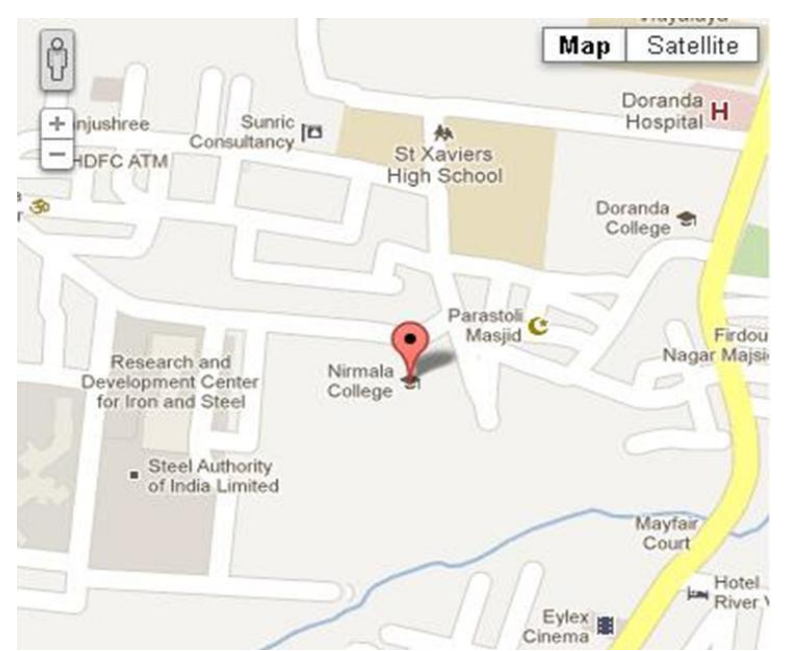

Fig 1: Study area (Courtesy: Google Maps).

\section{Systematic position}

$\begin{array}{lcl}\text { Division } & : & \text { Phanerogams } \\ \text { Class } & : & \text { Dicotyledons } \\ \text { Order } & : & \text { Urticales } \\ \text { Family } & : & \text { Ulmaceae } \\ \text { Genus } & : & \text { Holoptelea } \\ \text { Species } & : & \text { H. integrifolia } \text { Planch. }\end{array}$

Holoptelea integrifolia Planch. is a road side tree (Fig. 2). It belongs to family Ulmaceae which comprises 15 genera and 200 species. It is commonly known as chilbil, kanju in Hindi, chirivilva, poothigam in Sanskrit, njettaval in Malayalam and India elm tree in English. The plant species originated from pacific island. It is distributed over tropical and temperate region of northern hemisphere. Holoptelea integrifolia is considered to be native to Asian-tropical region including India, Nepal, Sri Lanka, Cambodia, Laos, Myanmar, Vietnam and China. It is a large deciduous tree with spreading branches and grows up to 30 to $35 \mathrm{~m}$ in height and $3 \mathrm{~m}$ girth. Bark is whitish, yellow grey, covered with blisters, peeling in corky, exfoliate with regular intervals. Leaves are simple, alternate, elliptic ovate, entire glabrous with cordate base, acuminate, nerves $5-8$ pairs, $5-13 \mathrm{~cm}$ long and 3.2 to $6.3 \mathrm{~cm}$ wide. The bark when cut and the leaves when crushed emit an unpleasant odour. Flowers are polygamous greenish yellow to brown in short racemes or fascicles. In male flowers, 8 stamens and in bisexual flowers 5 stamens are present, basally adnate to tepals, ovary is unilocular and stalked, style very short (2.5 to $4 \mathrm{~mm})$ long; stigmas 2 in number. The flower appear at the scars of fallen leaves on tree from February to March. Fruits are one seeded samara, light brown, obliquely elliptic or orbicular, winged and stalked, indehiscent, 2.5 to $3.5 \mathrm{~cm}$ long 1.5 to $2.5 \mathrm{~cm}$ wide. The fruits are seen during month of April to May. Seeds are small, whitish, kidney shaped, flat samara. Habitat moisture and shady area is favourable for survival. The tree is not frost hardy.

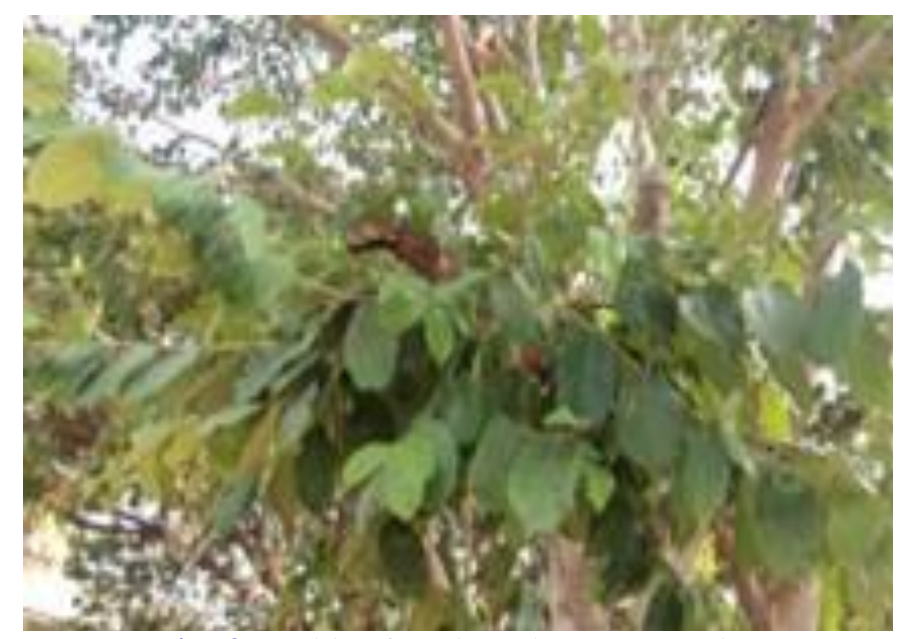

Fig. 2: Habit of Holoptelea integrifolia. 


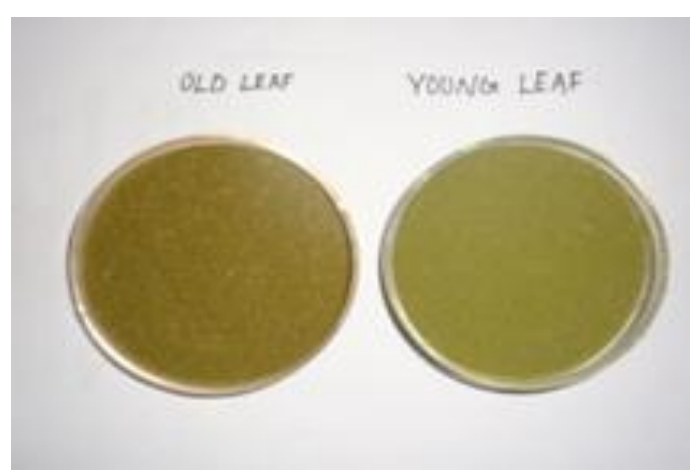

Fig 3: Powdered sample.

The plant Holoptelea integrifolia is used traditionally for the treatment of inflammation, gastritis, dyspepsia, colic, intestinal worms, vomiting, wound healing, leprosy, diabetes, hemorrhoids, dysmenorrhoea and rheumatism. Bark and leaves are used as bitter astringent, thermogenic, anti- inflammatory, digestive, carminative, laxative, anti- helmintic, depurative, repulsive urinary astringent and in rheumatism the plant is being used by tribal people for their medicinal properties. Decoction of the leaves is used to regulate fat metabolism, treat ring worm eczema and cutaneous disease. Bark and leaf paste of the plant are applied externally on the white patches or leucoderma. Leaves are also used for treating intestinal cancer. Leaf bud mixed with lime juice and applied externally to affected area for treatment of hair loss by infection and treatment of herpes infection. A handful of bark and leaves ground with 15 pepper seeds, one bulb of garlic in rice washed water (Parinitham et al., 2004).

\section{Biochemical analysis}

The biochemical screening of leaves and ethanolic extract of Holoptelea integrifolia were analysed by standard methods and shown various biochemical constituents such as protein and carbohydrates/ reducing sugars.

\section{Preparation of ethanolic leaf extract}

The young and matured leaves were collected from the Holoptelea integrifolia and washed twice in running tap water. The leaves were dried allowed to dry under the shade. The dried leaves were powdered by pulverizer. Fig. 3 shows the powdered leaf material of Holoptelea integrifolia. Thirty gram of this powder was extracted with $375 \mathrm{ml}$ of ethanol under Soxhlet apparatus for 24 hours. The collected extracts were used for further analysis. The following parameters were analyzed by the methods:

- Extraction and estimation of total soluble carbohydrate by Anthrone methods (Hedge and Hofreiter, 1962).

- Extraction and estimation of total proteins by Lowry's methods (Mattoo, 1970).

\section{Results and discussion}

The leaves of Holoptelea integrifolia ethanolic extract showed the presence of carbohydrates and protein (Vinod, 2009). Carbohydrates and proteins are present in both leaves but high amount of carbohydrates are present in the young leaves of Holoptelea integrifolia. The ethanolic extract of the leaves of Holoptelea integrifolia have significant anti-diarrheal activity and supports its traditional uses in herbal medicine.

The effect of acute exposure of sulphur dioxide on the metabolism of Holoptelea integrifolia plants has been observed. The biochemical changes include accumulation of free sugars; especially the reducing sugars in the tissue associated with the deposition of starch, and enhanced acid phosphate in exposed plants (Farooq et al., 1985).

Table 1. Carbohydrates and proteins present in the ethanolic extract of young and old leaves of Holoptelea integrifolia.

\begin{tabular}{llll}
\hline S. No. & Phytochemicals & HIEE(Y) & HIEE(M) \\
\hline 1 & Carbohydrates & ++ & + \\
2 & Proteins & + & + \\
\hline
\end{tabular}

(++ indicates strongly present and + indicates moderately present)

HIEE (Y): Holoptelea integrifolia ethanolic extract of young leaves

HIEE (M): Holoptelea integrifolia ethanolic extract of matured leaves 
Table 2. Carbohydrate and protein contents present in the young and matured leaf extract of Holoptelea integrifolia.

\begin{tabular}{llll}
\hline S. No. & Samples & Carbohydrates $(\mathbf{m g} / \mathbf{g})$ & Proteins $(\mathbf{m g} / \mathbf{g})$ \\
\hline 1 & HIEE $(\mathrm{Y})$ & 62.0 & 27.2 \\
2 & HIEE $(\mathrm{M})$ & 39.0 & 19.0 \\
\hline
\end{tabular}

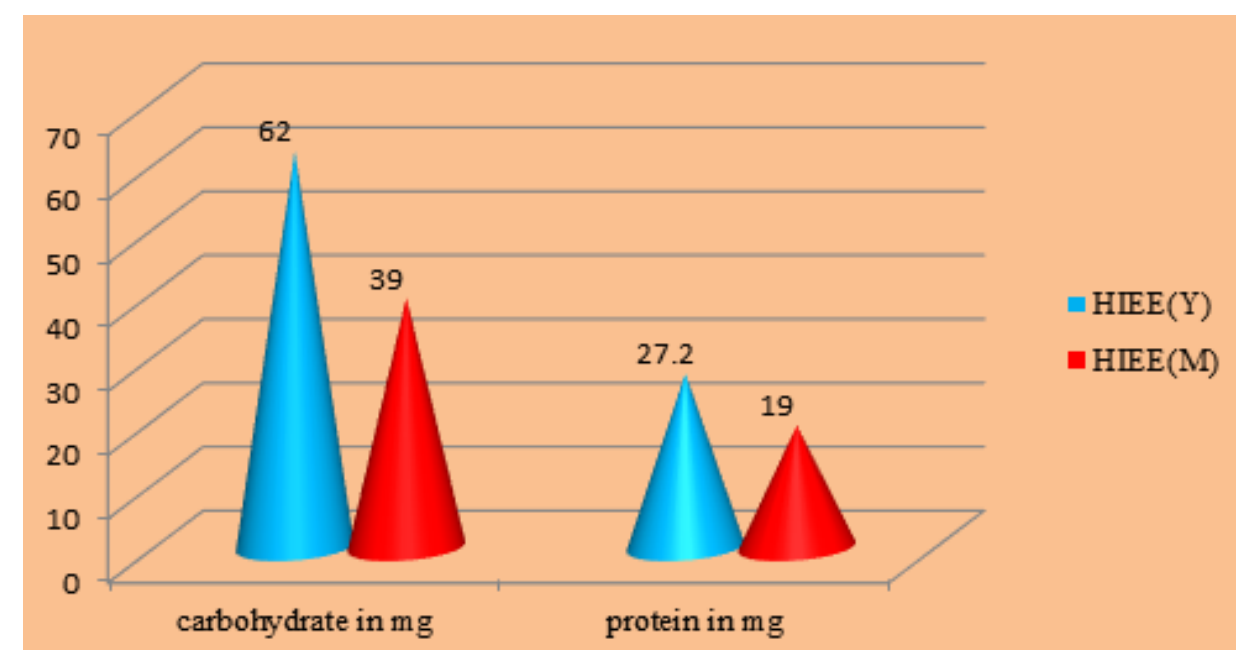

Fig. 4: Carbohydrate and protein contents $(\mathrm{mg} / \mathrm{g})$ present in the young and matured leaves of Holoptelea integrifolia.

Anthrone Method and Lowry's method was used to determine the content carbohydrate and protein respectively. The young leaves of Holoptelea integrifolia contain more carbohydrate and protein than the matured leaves. People have to find the way back to natural medicinal herbs. The secondary metabolites are naturally synthesized in all parts of the plant body especially bark, leaves, stem, root, flower, fruits, seeds, etc.

\section{Conflict of interest statement}

Authors declare that they have no conflict of interest.

\section{References}

Akbar Farooq, M., Masood, A., Beg, M.U., 1985. Effect of acute exposure of sulphur dioxide on the metabolism of Holoptelea integrifolia plant.
39, 189-205.

Gibson, E.L., Wardel, J., Watts, C.J., 1998. Fruit and vegetable consumption, nutritional knowledge and beliefs in mothers and children. Appetite. 31, 205-228.

Hasler, C.M., Blumberg, J. B., 1999. Symposium on Phytochemicals: Biochemistry and Physiology. J. Nutr. 129, 756S-757S.

Hedge, J.E., Hofreiter, B.T., 1962. In: Carbohydrate Chemistry, 17 (Eds.: Whistler, R.L., Be Miller, J.N.), Academic press, New York.

Mattoo, R.L., 1970. Influence of sodium chloride on the colorimetric determination of protein in plant tissues rich in phenols-phenolases. Indian J. Biochem. 7, 82.

Parinitham, M., Harish, G. U., Vivek, N.C., Mahesh, T., Shivanna, M.B., 2004. Ethnobotanical wealth of Bhadra wild life santuary in Karnataka. Indian J. Trad. Knowl. 3, 37-50.

\section{How to cite this article:}

Nithya, B., Arul Sheeba Rani, M., 2018. Preliminary biochemical analysis of the ethanolic leaf extract of Holoptelea integrifolia Planch. (Family-Ulmaceae). Int. J. Curr. Res. Biosci. Plant Biol. 5(3), 49-52. doi: https://doi.org/10.20546/ijcrbp.2018.503.007 